to what types of statutes are constitutional, it seems that, except for the rare situation authorized by this decision, custodial power should be vested solely in the insurer's domiciliary state. Such a ruling would provide a practicable solution $^{52}$ in conformance with other types of abandoned property legislation.

\title{
SELECTION OF JURORS BY VOIR DIRE EXAMINATION AND CHALLENGE
}

The challenge for cause and its companion device the peremptory challenge are primarily designed to secure an impartial jury by the elimination of unduly prejudiced jurymen.' While challenges for cause permit rejection of prospective jurors on the ground of provable and legally cognizable evidence of partiality, ${ }^{2}$ peremptories permit further rejections for a real or imagined partiality that is less easily designated and proved. ${ }^{3}$ Essential to

52. See Cardozo, J., in Severnoe Securities Corp. v. London and E. Ins. Co., 255 N.Y. 120, 123-124, 174 N.E. 299, 300 (1931): "At the root of the selection [of legal situs] is gen= erally a common sense appraisal of the requirements of justice and convenience in particular conditions. . . ."

1. See Betts v. United States, 132 Fed. 228, 236 (1st Cir. 1904). And see Bodin, Sclecting A Jury, Practising Law Inst. 5, Series I, no. 10 (1946) and Notes, 11 New. L. BulL. 426 (1933), 14 St. Jorn's L. REv. 142 (1939), 11 Tex. L. Rev. 373 (1933).

The word "juryman" is used throughout this discussion as synonomous with "prospective juror."

2. See 1 Thompson, Trials $\$ 71$ (2d ed., Early, 1912); Bodin, supra noto 1, at 5.

3. $4 \mathrm{BL}$. Conss. $* 353$. Recent English cases in which the accused used peremptory challenges to keep women off the jury provoked the following comment: "He (the accused) may well be an innocent man-and the law in every case presumes him so; if he feels, however unreasonably, that some of the jury will not give him a fair hearing, he may be unable to give his evidence in as confident a manner as he otherwise vould have done, with the consequence that an innocent man may be unjustly convicted. . . . Justice will not be seen to be done if a man is convicted by a tribunal which he believes (albeit unrcasonably) is necessarily prejudiced against him." 76 L.J. 223 (1933).

To the extent that peremptories further the goal of reducing extremes of partiality they also tend to minimize hung juries. See State v. Shores, 31 W.Va., 491, 499, 7 S.E. 413, 417 (1888) ; Hayes v. Missouri, 120 U.S. 68 (1887).

The right of peremptory challenge has an ancient lineage in felony prosecutions at common law. See 1 Thompson, Truals $\$ 42$ n.54, n.55 (2d ed., Early, 1912), In England, although this right has extended to some other crimes, it has never been granted in civil cases. See Thompson \& Merrian, Jurres $137-42$ (1st ed. 1882) ; Moore, Voir Dirc E.ramination of Jurors I, 16 GEo. L.J. 438, 444-53 (1928) ; Note, 11 NEB. L. BULL. 426 (1933). In the United States, however, the national and state legislatures have granted peremptories in civil as well as criminal cases. See, e.g., 36 Stat. 1166 (1911), 28 U.S.C. \& 424 (1946). Most courts maintain that the legislature may withhold, as well as regulate, thir 
the effective exercise of either, the voir dire examination has proved so far the only significant means of ascertaining the facts of prejudice."

Since both challenges for cause and peremptories are merely rejection devices, ${ }^{5}$ their success must depend, in the last analysis, on the existence of a panel containing a high proportion of unprejudiced prospective jurors. Although constitutions and statutes prescribe qualifications for individual jurymen which are designed to eliminate partiality and incompetence, ${ }^{\circ}$ the jury list as a whole need provide only a roster of mentally sound individuals who represent a cross section of the community; ${ }^{7}$ and these may well be prejudiced as to particular issues. When all or most of the jurymen impanelled are prejudiced, as where newspapers have influenced the whole community to prejudge a case, only a limited number will normally be challengeable for cause, and not even a generous allowance of peremptories ${ }^{8}$ can secure an impartial jury. ${ }^{9}$

right. See, e.g., Walter v. People, 32 N.Y. 147 (1865) ; accord, Stilson v. United States, 250 U.S. 583 (1919).

Some doubt is cast upon the wisdom underlying peremptory challenges by a study, which unfortunately is too limited to be given grest weight, indieating that the effect of peremptories is to lower the jury's standard of intelligence. See CALIE: IION OF JURORS $38-41,89$ (1924).

4. Parties seldom can afford to conduct private investigations of prospective jurors. It is for this reason that courts permit extensive and detailed voir dire examination of the jurymen by the parties. See MfoscrzZISKIR, TRIAL BY JUnY $\$ 120$ (2d ed. 1930).

5. See Thoxspson \& Miezruar, Juries $\$ 159$ (1st ed. 18S2) and Nates, 10 So. Crluf. L. Rev. S9, 91 (1936), 11 TEx. L. REv. 373 (1933). See also Betts v. United States, 132 Fed. 228 (1st Cir. 1904) ; Searle v. Roman Catholic Bishop, 203 MIass. 493, 499, 89 N.E. 809,811 (1909).

6. For a discussion of the qualifications for jury service see Blume, Jury Sclcetion Analyzed, 42 MICr. L. REv. 831 (1944). Jurors in a federal court must have the qualifieations of those in the highest court of the state. 36 STAr. 1164 (1911), 28 T'.S.C. $\$ 411$ (1946).

7. Sec, e.g., Glasser v. United States, 315 U.S. 60, 85-6 (1942) ; Smith v. Texas, 311 U.S. 128, 130 (1940). For criticism and suggestions for improving the selection of jurymen, see Clark and Shulman, Jurry Trial in Ciril Cases-A Study in Judicial Adninistration, 43 Yale L.J. 867, 874-9 (1934) ; Edling, Obtaining Jurors, 1 TEx. LAw \& Lrgis. 63 (1947) ; Potts, Desirability of the Federal Systcit of Selection of Jury, 2-3 Inarro S.B. 53 (1926).

8. Statutory provisions specifying the number of peremptories allowed vary as to whether the action is civil or criminal. In civil cases, from two to five peremptories are generally permitted. See, e.g., ALA. CoDE, tit. 30, \$53 (1940); Coms. GEw. STAт. \$ 5577 (1930); MLAss. GEN. LAws, c. $234, \$ 29$ (1932). In criminal cases the number varies from two to more than twenty, with the defendant frequently allowed far more than the prosceution. See, e.g., GA. CoDE $\$ 59-\$ 05$ (1933); Idamo Code $\$ 19-1916$ (1932); MIo. Ret. Stax. $\S 4063$ (1939); NEv. Cosp. LAws $\$ 10942$ (1929). The legislatures have used difiering criteria for determining the number of peremptory challenges to be permitted. See, c.g., MicE. REv. StAT. $\$ \$ 28.1035,28.1036$ (1935) (punishment involved determines number of peremptories); Mo. REv. STAT. $\$ 4063$ (1939) (cases tried in cities of more than 100,080 people receive more peremptories than cases tried elsewhere).

In cases involving joint parties where the interests of the partics are idcntical, and no hostility exists between them, "party" is usually interpreted so that the specified number of 
With this limitation, however, and with the further limitation that the effectiveness of the peremptories must depend in part on intuition, the challenge technique can aid in the selection of a jury devoid of extremes of partiality.

Unfortunately, the procedures which at present characterize the examination and challenge of jurymen permit able lawyers to employ the voir dire examination to influence the jury panel, prevent the optimum utilization of challenges for eliminating partial jurymen, obscure, in the eyes of appellate courts, the fundamental issue of impartiality, and waste time and money both at the trial and on appeal.

Under the present practice, courts allow lawyers wide latitude during the voir dire examination in eliciting information upon which to support a challenge for cause, and permit even further inquiry on which to base peremptories. ${ }^{10}$ While the procedure in many cases permits jurymen to be

challenges is given to each "side," regardless of the number on a side. Dricfus v. Levy, 140 So. 259 (La. 1932) ; see Stroh v. Hinchman, 37 Mich. 490 (1877). A few courts, however, vehemently refuse to deny any party his full number of peremptories. E.g., Mourison v. Hansen, 128 Conn. 62, 20 A.2d 84 (1941). For general discussion sec 1 Turompson \& MerriaM, Juries 152-3 (1st ed. 1882) ; Notes, 25 Mich. L. Rev. 309 (1927), 11 Tex. L. REv. 373 (1933).

9. Such a result is claimed in the current proceedings against the leaders of the Communist Party in New York. The defense insists that it is impossible for it to secure an impartial jury from a jury list which "excludes" Jews, Negroes, and other oppressed minorities, while drawing most of its members from white, land-owning, Protestant groups. See N.Y. Times, Jan. 28, 1949, p. 1, col. 2 ; N.Y. Times, Feb. 3, 1949, p. 1, col. 1; N.Y. Times, Feb. 5, 1949, p. 1, col. 7.

Where a good jury list is provided, however, the converse is equally true. Thus, the English practice seems to indicate that impartial juries may be selected without extensive use of peremptories. A 1929 rape case in which the defendant used peremptory challenges to keep women off the jury provoked considerable comment in British legal periodicals. The use of peremptories was called "a rare experience," Challcnge of Jurors, 68 L.J. 225 (1929) ; "of doubtful expediency," Challenging the Jtiry, 73 SoL. J. 619 (1929); and "antiquated," Challenging Jurors, 93 Just. P. 621 (1929).

10. The steady tendency today is toward permitting broad inquiry by counsel to disclose "any prejudice or bias on the part of jurors." Murphy v. United States, 7 F.21 85, 86 (1st Cir. 1925); although it is recognized that a juror may become hostile merely because he has been closely interrogated by an attorney. See Rutherford v. State, 32 Neb. 714, 717, 49 N.W. 701, 702 (1891):

Courts frequently pay lip service to a requirement that the inquiries be "reasonable and pertinent," "while in fact permitting extensive questioning. Sec Henwood v. People, 57 Colo. 544, 143 Pac. 373 (1914) (hypothetical questions involving accused's defense permitted) ; Olguin v. Thygesen, 47 N.M. 377, 143 P.2d 585 (1943) (in a tort action, inquiry as to interest in insurance companies allowed). See Swift \& Co. v. Platte, 68 Kan. 1, 6-7, 72 Pac. 271, 272 (1903), on rehearing, 68 Kan. 10, 74 Pac. 635 (1903): "Considerable latitude should be allowed counsel in the examination of jurors, so that all who have bias or prejudice, or are otherwise disqualified, may be eliminated, but the inquiry should never be made to introduce extraneous matter of a prejudicial character that may improperly influence the verdict. Questions are not to be barred merely because the answers elicited would be incompetent under the issue in the case; nor are parties to be hampered in a thorough examination, made in good faith, to keep off the panel partial, prejudiced and uns 
questioned as a group, frequently they are individually interrogated; ${ }^{11}$ and, in either event, challenges, both peremptory and for cause, are made orally in the presence of the prospective jurors. ${ }^{12}$

The timing and order of challenges is prescribed by statute in a number of states. ${ }^{13}$ In the absence of statute, there is generally no uniform state rule as to timing and order, the matter being left to the trial court's discretion. ${ }^{1 /}$ The court may require a party to challenge peremptorily as well as for cause, immediately following the examination of each prospective juror by both parties, ${ }^{15}$ or, sometimes, before the other party has had a chance to examine. ${ }^{16}$ Under this rule, the court may insist that the same party challenge first each time, both peremptorily and for cause, ${ }^{17}$ or that the parties alternate as to which challenges first. ${ }^{13}$ On the other hand, the court may require that a group of jurymen unchallengeable for cause be selected before permitting the parties to exercise their peremptories. ${ }^{10}$ And again, the court may insist that the parties exercise their peremptories alternately," or that one party exhaust all peremptories before the other party begins to challenge. ${ }^{21}$ Where the defendant has a greater number of challenges than the plaintiff, the court may direct the defendant to challenge until he is reduced to numerical equality with the plaintiff, after which the parties

fit men. The inquiry may be extended to the social and business relations of the proposed jurors with the parties to the action or with any one connected with the litigation. It should, however, as before stated, be conducted in good faith, by pertinent inquirics, for the purpose of sifting the panel and excluding those who are disqualified or objectionable by challenges peremptory or for cause."

In populous communities jurors are seldom challenged for cause as the result of information elicited from the voir dire examination. Usually counsel is looling for information that will help him in using his peremptories. Athinson, The Foir Dire Examination of Jurors in Kansas, 1 J.B.A. KaN. 125, 127 (1932).

11. 50 CJ.S. Juries $\$ 194$.

12. Some trial courts permit peremptories to be submitted to the court by lists, first by one party, and then, following the removal of the challenged jurors, by the other.

13. Only a minority of states have enacted statutes governing the matter. Examples are: IdAHo Cone $\$ \S 7-202,19-1930$ (1932) ; MONT. Rev. Code $\$ 9343$ (1935).

14. See notes 17-21 infra.

15. See sources cited in note 18 infra.

16. See sources cited in note 17 infra.

17. For discussion see Commonwealth v. Marion, $232 \mathrm{~Pa} .413,420-3,81$ Atl. 423, 425-6 (1911) ; Philbrook v. United States, 117 F2d 632, 635-6 (8th Cir. 1941), ccrl. dcricd, 313 U.S. 577 (1941). See Bodin, Sclecting a Jury, Practising Law Irist. 7, Series I, no. 10 (1946).

18. Where this is done, if the plaintiff challenges first as to juryman $A$, then defendant would have the first challenge as to juryman $B$, etc. Instances of this practice are found in: Weaver v. People, 47 Colo. 617, 108 Pac. 331 (1910) ; State v. Lake, 99 Kan. 157, 163 Pac. 618 (1916). See Bodin supra note 17, at 7.

19. This practice is illustrated in Vance v. Richardson, 110 Cal. 414, 42 Pac. 909 (1895) ; Gilchrist v. Brande, 58 Wis. 1S4, 15 N.W. S17 (1SS3); Sce Commonwealth v. Marion, $232 \mathrm{~Pa}$ 413, 422, \$1 Atl. 423, 425 (1911).

20. See sources cited in notes 17 and $1 S$ supro.

21. See Mo. Rev. Stat. $\$ 4065$ (1932), and Bodin, supra note 17, at 7. 
alternate; ${ }^{22}$ but the more common practice requires the defendant to use several peremptories at a time so that both parties exhaust their challenges at the same moment. ${ }^{23}$ Whatever the order of challenge, most courts insist that the right to challenge a prospective juror peremptorily is waived by non-challenge at the prescribed time, ${ }^{24}$ although a considerable minority permit such challenge until the juror is actually sworn, even where the party has previously indicated oral acceptance. ${ }^{25}$

As a result of extended voir dire examination of jurymen by counsel, attorneys are given an excellent opportunity to predispose the jury in their favor. On the other hand, where challenges for cause are made orally in the presence of prospective jurors, there is a distinct possibility that an unsuccessful challenge will prejudice a prospective juror against the objector. To a lesser degree, even a peremptory, if exercised in their presence, may prejudice the remaining jurymen.

If the challenger resorts to a peremptory to remove a juror so prejudiced, the number of peremptories available for eliminating other partial jurors is to that extent reduced. In those jurisdictions where challenges must be exercised as each juror is selected, the utility of the peremptory in eliminating extreme partiality is further impaired. Here, challenges may be exhausted against early prospective jurors who are somewhat partial, thus preventing

22. E.g., State v. Brown, 16 Del. 380, 384-5, 36 At1. 458, 459 (1896).

23. For examples of this practice see Lyon v. State, 116 Ohio St. 265, 155 N.E. 800 (1927) ; State v. Eddon, 8 Wash. 292 (1894).

24. In St. Clair v. United States, 154 U.S. 134, 147-8 (1894) a rule of the district court provided that " $a$ juror shall be challenged, or accepted and sworn, in the case as soon as his examination is completed, and before the examination of another juror." The Supreme Court denied the defendant's claim that he had a constitutional right to examine all jurors before challenging any peremptorily, stating that the rule "is not inconsistent with any settled principle of criminal law, nor does it interfere with selection of impartial juries." Similar decisions under state constitutions are People v. Reynolds, 16 Cal. 129 (1860); State v. Hartley, 22 Nev. 342, 40 Pac. 372 (1895); see Munday v. Commonwealth, 81 Ky. 233 (1883). See generally BrerLy, JURIES AND JURY Trials 132 (1908), and Note, 21 NEy. L. REv. 174 (1942). Where good cause is shown before the jury is sworn, however, the courts will permit a party to use a "peremptory" after acceptance of the juror. State $v$. Potter, 18 Conn. 165 (1846). Why the challenge is not deemed to be for cause is not clear.

25. O'Connor v. State, 9 Fla. 215, 227 (1860) ; State v. Anderson, 4 Nev. 265 (1868). This view is supported in 1 Thompson, Trials 121-2 (2d ed., Early, 1912).

In Avila v. United States, 76 F.2d 39, 41 (9th Cir, 1935) a rule of the Federal District Court provided, in part, that "the box shall be filled from time to time, in the discretion of the court. After all peremptories have been taken, or the parties satisfied, the jury shall then be sworn as a body to try the cause." The Circuit Court held, in a divided opinion, that the trial court's rule did not confer discretionary power on the trial judge to require peremptories to be exercised at a time when the box was not filled. The court advanced the unfounded notion that such procedure deprived the defendant of his right of peremptory challenge, and the completely fallacious theory that he was thereby deprived of his constitutional right to trial by jury. This decision has been widely eriticized as enabling the defendant "to compare and choose as between jurymen so as to preserve as the final twelvo those who appear to him to be most favorable." Note, 21 NEv. L. REv. 174, 178 (1942), 10 So. Calif. L. Rev. 89 (1936). 
the removal of later jurymen who may be more partial. Or, counsel may accept a partial juror for fear that a later juror will be more partial, only to find that no more-partial jurors are called.

Furthermore, all of these procedures, in that they tend to emphasize tactical advantages ${ }^{26}$ to one side or the other, tend to obscure the real issue-whether a particular method of jury selection actually produces an impartial jury. Most appeals are taken on procedural points, and even though impartiality should be the only issue of importance, it is not difficult for a court to decide the case from the viewpoint of procedure for procedure's sake, rather than on the basis of undue prejudice or even abnormal partiality. 27

To insure that the challenging system best fulfills its function of aiding in the selection of impartial juries, the voir dire examination should be con-

26. The importance which lawyers frequently attach to these tactical advantages is illustrated by the following quotation. "And it has come to be well recognized gcnerally that a litigant may get the best legal service obtainable; he may have, to many right thinl:ing minds, the preponderance of testimony and right; but if his lawyer 'can't picls a jury' his chances for success are very slim." Hon. T.D. Samford, Peccernnigs, Aha. St. Bar, Ass's 143 (1928).

27. A recent Connecticut case, De Carlo v. Frame, 134 Conn. 530, 58 A.2d \$46 (1948) is illustrative of the extremes to which an appellant court can go in emphasizing procedure.

The jurors were examined by both parties and aiter twelve had been ascepted and were ready to be strom, the defendant attempted to esercise a peremptory challenge, although no new facts had been adduced. In granting the challenge, the trial judge spolie of a "right" in the defendant, but later explained in his memorandum to the apgellate court that he had acted in his discretion. The Supreme Court of Errors reversed, holding in a divided opinion, that acceptance of the juror constituted waiver of the right to challenze peremptorily. The court went on to say, however, that it would have affirmed if the trial court had acted in its discretion, rather than on the basis of a "right."

The plainitf in the De Carlo case failed completely to show that he had becn prejudiced by the questioned challenge, and the majority opinion glossed over the question of prejudice without mention. The dissenting judge, hovever, pointed out that no prejudice was shown. In fact, the appellant made no attempt to show prejudice in his bricf. He did state that, "[t]he plaintiff was irreparably harmed," by the permitted challenge, but no indication was given as to why his case was thus damaged. Brief for Appallant, p. 20, De Carlo v. Frame, supra.

Thus the $D e$ Carlo case appears to accomplish little other than to provide another trial by an impartial jury for a cause which had already been decided by an impartial jury. "... [W] hile the disallowance of a good cause of challenge will work a reversal of the judgment, an improper allowance of a cause of challenge will not necessarily have this effect. A qualified juror'may be rejected, and still a jury of lawilul men, against whom there is no objection, may be obtained. ... Obviously, the only affect of granting ... [ [a motion for a new trial] would be that the prisoner would have to talse the vcrdict of an-

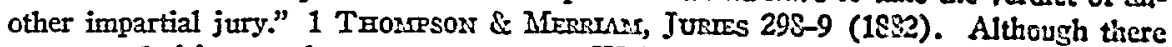
are some decisions to the contrary, see, e.g., Walter v. State, 208 Ind. 231, 195 N.E. 268 (1935) ; State v. Bertrand, 167 La 374, 119 So. 261 (1928), most cases hold that vrongful exclusion of a competent juror is not cause for reversal in the absence of a showing of prejudice Watson v. State, 63 Ind. 548 (1878); People v. Prior, 294 N.Y. 405, 63 N.E. 2d 8 (1945). 
ducted by the court itself, and jurymen should be dismissed for cause on its own motion. In order that no proper line of inquiry be neglected, however, the parties should be permitted to request the court to question particular jurymen on subjects believed to be pertinent in determining their qualifications. At the conclusion of the voir dire examination, peremptory challenges by the parties should be conveyed to the court in such a manner as to conceal from the prospective jurors the particular challenges exercised by each party. Under a suggested method, the court would select a number of prospective jurors, unchallengeable for cause, equal to the total number of peremptories allotted to all parties plus twelve. The parties would then simultaneously submit to the court lists of those jurors whom they wished to challenge peremptorily. The first twelve names remaining from the original panel would constitute the jury.

The court-conducted voir dire, though still a minority practice, ${ }^{29}$ is becoming increasingly popular. On the other hand, a requirement that peremptories be submitted simultaneously to the court is rarely, if ever, imposed today. But it has been sanctioned in the past as within the trial court's discretion. ${ }^{29}$ In many jurisdictions, therefore, the adoption of both practices should be possible without altering either statute or appellate case law.

The court-conducted voir dire examination would effectively minimizo attempts by counsel to prejudice the jury in the pre-trial stage, since the examination of prospective jurors would be placed in the hands of a neutral third party, the judge. And the exercise of challenges for cause by the court avoids the risk of prejudicing jurors by a party's unsuccessful challenge. The simultaneous submission of lists to convey peremptory challenges to the court would prevent prospective jurors from discovering which party challenged particular jurymen and thus would complete the elimination of possible prejudice resulting from oral challenges by the parties themselves. Furthermore, peremptories would be utilized to the maximum in that parties would be enabled to survey the whole jury panel and eliminate at one stroke those most prejudiced against them.

28. For examples of this practice see Falter v. United States, $23 \mathrm{~F} .2 \mathrm{~d} 420$ (2d Cir. 1928) ; People v. Lahey, 256 Mich. 250, 239 N.W. 254 (1931); Funches v. State, 125 Miss. 140, 87 So. 487 (1921). Also see, Brown v. S.H. Kress \& Co., 170 S.C. 178, 179, 170 S.E، 142 (1933).

The movement for court-conducted voir dires came from a recommendation of a conference of Senior Circuit Court Judges. Moore, The Voir Dire Examination of Jurars, II, 17 GEo. L. J. 13, 14 (1928). Many states now permit the trial court, in its discretion, to conduct the voir dire examination. See, e.g., MASs. GEN. LAws, c. 234, $\$ 28$ (1933). The federal courts have this same discretion. FED. R. Civ. P. 47.

29. In State v. Hays, 23 Mo. 287 (1856) the trial court required that both parties exercise their peremptories simultaneously. The Missouri Supreme Court held that although simultaneous use of peremptory challenges might lead to possible duplication of jurymen challenged, this was no abuse of discretion for the parties had exercised the full number of peremptories to which they were entitled by statute, and had not been prejudiced in anyway. 